\title{
Homestay Employees Empowerment In Front Office Division Toward Competency Standard Practices To Improve The Services Quality In Kupang City
}

\author{
Elsa Dian Taimenas, Imelda R. Pellokila, Yunita Novitasari Rihi, Sheila Day \\ \{elsadian1988@gmail.com, imelda.pellokila@gmail.com, nitharihi12@gmail.com, \\ sheiladay866@gmail.com\} \\ Polytechnic State of Kupang, Indonesia
}

\begin{abstract}
Kupang City is a multi-cultural and transit city for tourists who want to continue their journey to other islands in East Nusa Tenggara. Thus, Kupang City can be the potential to bring tourists with short length stay visits and the homestay significantly increases every year. For visitors, the role of the front office and hospitality service functions, even employees or hosts play an important role in supporting visitor service activities. The research uses a descriptive approach and sample methods by collecting survey data, observations, questionnaires, and interviews assisted by National Occupational Certification Schemes, which is front office employees and hosts of the homestay. As a result, this study determines the standard competency level of the front office employees or hosts services and help them in improving the quality of their services so that tourists have the maximum experience while staying and exploring the exotic of Kupang City.
\end{abstract}

Keywords: Homestay, Competency Standard, Hospitality, Front Office, Community Based Tourism

\section{Introduction}

The Tourism Industry as a part of tourism businesses that are interrelated to produce goods or services to meet the tourist's needs in the organization of tourism. In the Law of the Republic of Indonesia Number 10 of 2009 about Tourism, Tourism is also multi-dimensional and multi-disciplinary. The development of tourism from recreational activities to economic activities, making tourism activities are not different from other industrial activities such as a chain of activities that are so complex and involve various sectors with physical geographical, socio-cultural, and socio-economic dimensions.

Table 1: Domestic and International Tourist Arrival Number to Kupang City in 2013 -2017 [1].

\begin{tabular}{ccccc}
\hline No. & Year & Domestic Tourists & International Tourists & Amount \\
\hline 1. & 2013 & 179.839 & 6.242 & 186.081 \\
2. & 2014 & 149.914 & 3.607 & 153.521 \\
3. & 2015 & 184.975 & 7.530 & 192.505 \\
4. & 2016 & 203.449 & 6.045 & 209.494 \\
5. & 2017 & 260.651 & 6.530 & 267.181 \\
\hline
\end{tabular}


The table above shows the foreign and domestic tourist visits to Kupang City. According to the data, the government increase active to develop the tourism industry, especially in Kupang city.

\section{Homestay and Community Participatory}

Homestay is one of the tourism initiatives by the government to encourage local people to get involved with tourism activities. The homestay business continues to grow rapidly in Kupang City. There are 31 homestays and 24 guest houses registered, including Chrisant Homestay, Djafar Homestay, EverGreen Homestay, and others. These activities are in line with the notion of this programmed to improve the locals' quality of life by encouraging them to communicate with the homestay tourists [2].

Homestay accommodation is a term associated with a private house with a particular culture, interaction with a host or a family, every space becomes public area [3]. Apart from the authentic experience and architectural of the host culture, homestay can offer cultural adventure [4]. Living in a homestay, tourists have the opportunity to experience firsthand the life of local families, with the comfort and simplicity of local characteristics. Homestay as a lodge has a significant role in tourism industry development because it serves as a place to stay for tourists and can learn the culture, characteristics, and habits of the surrounding community as long as tourists travel as an alternative than staying in a hotel. Luxury and sophisticated facilities are surely non- existent in homestay accommodation. The success of homestay business depends on the owner's capability as host and operator, which are characteristics of small and medium businesses [5].

The location of the homestay itself can be in the village closes to tourist attractions or even in the middle of the city depending on the tenants' needs. The location of the homestay is also accessible to any mode of transportation with clear signage shall be provided to guide guests to the homestay. The accommodations as facilities, the house, the bedroom, and the bathroom are the main criteria for the homestay. A homestay has the main function of a temporary residential building for tourists. As a building that uses for a certain period, it is like having a main facility such as a bedroom or privacy room that can use for resting, bathrooms and other public support spaces.

Community participation has been promoted and studied into various disciplines of study, including planning, geography, community development, and others. For the tourism field, this study focuses on conventional sustainable tourism which highlights communitybased practice in planning, development, and management in the developing world [6].

Some studies also reveal the same result, indicated that the success of community-based tourism or homestay programs depends on the local community participation [7]. Furthermore, to investigate the relationship between community participation and entrepreneurial success in the homestay business in Sabah, Malaysia. This study focuses on the homestay entrepreneurs in Sabah. The previous studies indicated a positive relationship between community participation toward entrepreneurial success [8]. For instance, with the contribution of these findings, the homestay program will be more useful for homestay entrepreneurs, where the Ministry of Tourism, Arts and Culture (MOTAC) at Sabah can offer the villager's economic benefits such as new job creation, business opportunities, improve family income, and improved standard of living as suggested [9].

The development of sustainable tourism considered the main requirement for the future of tourism development. It refers to originating from the people, by the people, and for the people [10]. The sustainable tourism is an important economic activity that properly developed can overcome several of development challenges, including poverty reduction, local economic 
development, peace and harmony of the community, and sustainable management of natural resources and the environment [11]. This approach is a model of community empowerment that provides more opportunities for local communities such as homestay to actively participate in tourism development activities and local businesses. This meaning is giving authority or power to local people to mobilize their abilities in managing local resources. Their position is as the main actor in making decisions and exercising control over policies that affect their lives [12].

Community-based tourism expects to provide benefits for the community, such as economic benefits so that environmental maintenance can be carried out properly by the local community. Meanwhile, in the concept of community-based tourism development, it is necessary to consider a concept of a balance between resources and residents, which is an integrated development in which the community is a key player in tourism activity. The success of the management of a tourist area with the concept of community-based management can measure by the creation of a harmonious relationship between local communities, natural resources, cultural resources, and tourists [13].

The collaboration system that formed in community-based tourism endeavored to run in harmony. The local government, the tourism industry, tourism objects (local communities and the natural environment), as well as tourists can carry out their activities well and get a contribution from these activities. Forms of popular tourism are consistent with nature, social and community, and allow interaction by sharing experiences between tourists and local communities [14]. In the tourism development, all parties should be able to carry out their functions by the statue and no party feels exploited in the end. Conservation and improvement of the quality of the environment increase the values of resources that are objects, try to explore and find other resources, and the most important thing is to balance the use of resources used with existing resources is needed in the workplace.

\section{Front Office and National Occupational Certification Schemes}

The office division is visitors arrived area and first meet with staff in an agency or company to create first impressions for the guest. The first impression is important in any industry, especially in the hospitality industry, because the industry is considered a service dominated by the industry [15]. Hospitality employees constantly interact with a different guest every day so they are the way that new guests are forming first impressions every day. Meanwhile, front office staff will handle any questions asked by visitors, and put them in the first contact with relevant people in the company. The term of front office is different from the term of back office. The term refers to company operations, personnel, accounting, payroll, the finance department and does not interact directly with customers.

The front office hotel is one of the departments or sections that directly provide services to guests, starting from prospective guests making room bookings / pre-arrival until guests stay and check out from the hotel [16]. The front office officer most known as a receptionist receives information about the guest and then will forward it to the relevant department in the company. The front office can also contact marketing or sales if customers have questions about sales or marketing. The front office or receptionist is an important position because this position will always be in contact with the guest.

There are many job desks from Front Office Division, with several important roles, they are a source of information, Hotel representatives, salespeople, public relations, data storage, diplomatic, and problem solver. A receptionist must have sufficient knowledge and insight about service to be able to provide guest ratings or views of the homestay. For employees or host in charge in a homestay, knowledge refers to the facts, skills, and other information that 
one holds about their field and their specific job. Additionally, by showing confidence when helping guests, a front desk employee can also make them trust that the employees at the hotel are knowledgeable in their fields and develops the customers' confidence in the employee and the hotel, which can help build customer loyalty [17]. In the hospitality industry, employees are one of the hotel's major resources and can give a hotel a competitive advantage and differentiate it from other hotels $[18,19]$. Therefore, the skills and qualifications of front desk employees are very important, as these employees play a significant role in building and maintaining the lodge industry image and reputation.

The employee must be competent in the workplace to protecting image and reputation in the hospitality industry. They must be certified and legal to make sure that they are competent as well as their job desks. Human resources management is an organization consists of people with formally assigned roles who work together to achieve the organization's goals [20]. Moreover, employees and organizations focus on the portfolio of skills that suit individuals for specific roles within an organization, and less on the "job" as traditionally defined. The effective organizations understand the portfolios of skills and other capabilities that drive their success, and how people possessing those portfolios of capabilities should be deployed at any given time to reap maximum benefits for the organization [21].

The term of competencies covers the knowledge, skills, know-how applied and mastered in a specific context [22]. 'Competency' within the Australian VET system is defined as the ability to perform particular tasks and duties to the standard of performance expected in the workplace. Standards are statements about the skills, knowledge, and attitudes that people must demonstrate in their jobs to meet required industry standards. They are benchmarks created by industry that used to establish levels of effective performance in tourism-related workplaces. They provide a framework to suit the needs of all the stakeholders (Industry, Governments, Training Providers, Trainees), regardless of their location and size. To be meaningful and relevant is important that the training and assessment associated with the standards conducted in such a way that it meets the specific needs of industry sectors and participating trainees. In this way, the real training needs of the industry met.

SKKNI are statements about what people must be able to do in the workplace - they are not designed to provide details on how people can acquire the necessary skills, knowledge, and attitudes. Indonesia Competency Standard (SKKNI) adopts the Regional Model Competency Standard. The standard development works started as early as 1999. For Front Office Division, National Occupational Certification Schemes Referencing to ACCSTP and CATC on Tourism Professional in the area of Front Office is used to access and measure the employee competency in the workplace [23]. This scheme is used as material to develop learning packages in job training and tourism education, especially in the field of the Front Office and in the implementation of the National Occupational certification. National Occupational of Front Office consists of Front Office Manager, Front Office Supervisor, Receptionist, Telephone Operator, and Bell Boy.

As mentioned above, that to be a competent employee must have and recognize as a legal or certified employee. Thus, for Front office employees, for Receptionist, Telephone Operator and Bell Boy must know their job desk very well. Competency requires the ability to apply relevant skills, knowledge, and attitudes consistently over time in the required workplace situations and environments. When the employee practices their competency in the workplace, service quality will develop by them during the services of the customer.

Kotler argues that two main factors affect service quality namely expected service and perceived service [24]. If the service received or felt is as expected by the guest, the service quality perceived as ideal quality, but conversely, if the service received or perceived is lower 
than expected, the service quality perceived poor. Zeithaml, et al in Tjiptono have conducted various studies on several types of services, and successfully identified five dimensions of characteristics used by customers in evaluating service quality, namely reliability, responsiveness, assurance, empathy, and tangible. The quality of reception services is a measure of how a receptionist serves the customer in a homestay, and receptionist services by employee or host are a service that is sold and then purchased by the guest [25]. The guest had more options to choose and to retain the guest and give them life experiences so that they became loyal guests.

\section{Research Methods}

The researchers used qualitative method to obtain relevant and rich data for this research. It is a suitable method to understand the perceptions related to Competency Standard when they try to do the personal assessment. A semi-structured interview was used to obtain a richer data on employee perceptions towards their personal competency. This research used a descriptive approach and sample methods by collecting survey data, observations, questionnaires, and interviews taken and assisted with indicators of ASEAN Homestay Standard are front office employees and host of the homestay as a part of the accommodation industry in Kupang City. Furthermore, National Occupational Certification Schemes Referencing to ACCSTP and CATC on Tourism Professional in the area of Front Office is used to access and measure employee competency in the workplace.

From 31 respondents, 27 respondents have collected the questions as personal assessment toward competency in Front Office Division. The researchers divided into three parts, receptionist, telephone operator and bell boy. After the interview with the host or owner completed, he or she asked to nominate the next potential individual who was either in the same category of contact or from the other two categories. Respondents divided into two gender, Male $44 \%$ and Female $56 \%$. Further, according to ages, $11 \%$ is $21-35$ years old, $30 \%$ is 36 - 45 years old and $59 \%$ is more than 45 years old. Most of them, $85 \%$ are entrepreneurs. The categories mean that respondents should be as the host or owner and employee who taking care of the job every day. The research analyzed by the percentage method and the representation that was done in graphical form. The data analyzed as per the responses obtained from the respondents and interpreted to draw the following conclusions. Through the statements that distributed by researchers in the questionnaire, the researcher can conclude how the empowerment of front office homestay division employees in applying competency standards to improve service quality in Kupang City. The interval formula can be used to obtain descriptive data to assist researchers in determining these averages [26].

\section{Findings and Discussions}

All data in tables were processed using averages calculation formula in Statistical Application named SPSS 23 [27]. There are three main statements of problem closely related to Front Office Division competency standard practices. First, asking about the functional competency standard understood by homestay front office employees. Second, how many homestay front office employees have been certified. Third, how to advance homestay front office human resources. After conducted the research, the questions above answered with some findings.

The first problem statement discusses how many the competency standards at the workplace understood by each employee or host who manages the homestay business. There are three types of sub work asked by the researcher, namely receptionist, telephone operator, and Bell boy. Table 2 below discussed the receptionist job desk handled directly by the host 
as well as the employee. There are 7 work types according to functional competency standards they stated that the employee was very capable and able to handle those kinds of job desk.

In carrying out working as a receptionist, the results obtained from respondents stated very capably up to $33.3 \%$ and $66.7 \%$ of respondents explained that providing lodging services to the guest. It means that hospitality services needed to welcoming guests, giving the first impression for guests staying at a homestay. The hospitality service will give the impression of hospitality, image, and satisfaction for guests. Meanwhile, another job desk such as receiving and processing a guest's reservation, they were very capable up to $59.3 \%$ and capable up to $40.7 \%$ of respondents. This number proves that it has become a habit or skill that often done in the process of booking a guest room.

Other findings found were also seen in the types of functional job desk that process financial transactions in a homestay that can be done up to $88.9 \%$ of respondents and prepare financial reports that can be done up to $81.5 \%$ of respondents. Therefore, the number explained even though the homestay has a small number, the financial processes for homestay operations and financial affairs with guests are still carried out by the system that is owned and used in daily homestay operations. The impact on homestay management is carried out consistently to maintain the homestay management ecosystem.

Table 2: Receptionist Functional Competency Standard [27]

\begin{tabular}{|c|l|c|c|}
\hline \multirow{2}{*}{ No. } & \multicolumn{1}{|c|}{ Statements } & \multicolumn{2}{c|}{ Percentages } \\
\cline { 3 - 4 } & & $\begin{array}{c}\text { Extremely } \\
\text { Component }\end{array}$ & Competent \\
\hline 1 & Providing lodging services to the guest & 33,3 & 66,7 \\
\hline 2 & Receiving and process a guest's reservation & 59,3 & 40,7 \\
\hline 3 & $\begin{array}{l}\text { Processing financial transactions in a } \\
\text { homestay }\end{array}$ & 11,1 & 88,9 \\
\hline 4 & $\begin{array}{l}\text { Maintaining incoming and outgoing reception } \\
\text { records }\end{array}$ & 29,6 & 70,4 \\
\hline 5 & $\begin{array}{l}\text { Processing purchase transactions for goods or } \\
\text { services both guests and homestay operational } \\
\text { services }\end{array}$ & 25,9 & 74,1 \\
\hline 6 & Making periodic financial records & 22,2 & 77,8 \\
\hline 7 & Preparing financial statements & 18,5 & 81,5 \\
\hline
\end{tabular}

After seeing the functional desk of the receptionist, the Telephone Operator was another concern, the officer in charge of handling all telephone communication services and became part of the Front Office Division. The telephone operator is the person responsible for preparing and providing incoming telephone connection services to the guests, as well as opening telephone lines if there are homestay employees who want to make phone calls to parties outside the homestay. From the results of the questionnaire in Table 3 below explained up to $55.6 \%$ of respondents are very capable up to $44.4 \%$ respondents can receive and connect incoming calls up to $74.1 \%$ of respondents can facilitate to complete phone calls. The data proves the telephone operator as a person who can carry out long-distance and internal communication of the company. The telephone operator must be able to understand the workings and telephone systems used to work properly and appropriately. 
Table 3: Telephone Operator Functional Competency Standard [27]

\begin{tabular}{|c|l|c|c|c|}
\hline \multirow{2}{*}{ No. } & \multicolumn{1}{|c|}{ Statements } & \multicolumn{3}{c|}{ Percentages } \\
\cline { 3 - 5 } & $\begin{array}{c}\text { Extremely } \\
\text { Competent }\end{array}$ & Competent & $\begin{array}{c}\text { Not yet } \\
\text { Competent }\end{array}$ \\
\hline 1 & Operating PABX & 44,4 & 55,6 & - \\
\hline 2 & $\begin{array}{l}\text { Receiving and connecting } \\
\text { incoming calls }\end{array}$ & 55,6 & 44,4 & - \\
\hline 3 & $\begin{array}{l}\text { Facilitating outgoing telephone } \\
\text { calls }\end{array}$ & 25,9 & 74,1 & - \\
\hline 4 & Providing hotel service information & 48,1 & 51,9 & - \\
\hline 5 & $\begin{array}{l}\text { Providing international information } \\
\text { services (IDD) }\end{array}$ & 33,3 & 63 & 3,7 \\
\hline
\end{tabular}

Bell Boy will be the other concern of Front Office Division, which is a position or section that helps guests in the affairs of luggage and transportation. Bell Boy have responsible and ensures that guests have to get service and warm welcoming. Moreover, responsible for handling guest luggage, transportation and information obtained by the guest efficiently, politely, and professionally. The results explained in Table 4 below as follows. The respondents expressed very capable up to $74 \%$ in providing porter services and also another functional competency standard related to the job description as a bell boy.

Table 4: Bell Boy Functional Competency Standard [27]

\begin{tabular}{|c|l|c|c|c|}
\hline \multirow{2}{*}{ No. } & \multicolumn{1}{|c|}{ Statements } & \multicolumn{3}{|c|}{ Percentages } \\
\cline { 3 - 5 } & $\begin{array}{c}\text { Extremely } \\
\text { Component }\end{array}$ & Competent & $\begin{array}{c}\text { Not yet } \\
\text { Competent }\end{array}$ \\
\hline 1 & Providing porter services & 74,1 & 25,9 & - \\
\hline 2 & $\begin{array}{l}\text { Providing lost and found } \\
\text { facilities }\end{array}$ & 66,7 & 29,6 & 3,7 \\
\hline 3 & $\begin{array}{l}\text { Initiatives and assisting } \\
\text { valuables luggage }\end{array}$ & 59,3 & 37 & 3,7 \\
\hline
\end{tabular}

The Results above explained the Front Office Division for homestay employees has mastered their skills. It appears from the results of each job desk explained that they have a good number can do the job desk above. In daily life, knowledge and skills are continuously applied to create employee habits and even good quality service for guests who stay at the homestay. In addition, to explain the functional competency standard as capabilities of Front Office Division, table 5 below also explains the roles and responsibilities that need to be known and carried out, in general, to improve the quality of service when guests stay at the homestay. The Interest things are from as many as $74.1 \%$ of respondents stated strongly agree that employees must have the ability for problem-solving and as many as $81.5 \%$ of respondents stated that an employee must be a good salesperson and public relations when dealing with guests. 
Table 5: Front Office Division Roles [27]

\begin{tabular}{|c|l|c|c|c|}
\hline \multirow{2}{*}{ No. } & \multirow{2}{*}{ Statements } & \multicolumn{3}{|c|}{ Percentages } \\
\cline { 3 - 5 } & & $\begin{array}{c}\text { Extremely } \\
\text { Agree }\end{array}$ & Agree & Fair \\
\hline 1 & Sources of information & 22,2 & 74,1 & 3,7 \\
\hline 2 & Sales person & 18,5 & 81,5 & - \\
\hline 3 & Homestay Representatives & 22,2 & 74,1 & 3,7 \\
\hline 4 & Data Storage & 70,4 & 29,6 & - \\
\hline 5 & Diplomatic & 66,7 & 29,6 & 3,7 \\
\hline 6 & Problem Solving & 74,1 & 25,9 & - \\
\hline 7 & Public Relation & 18,5 & 81,5 & - \\
\hline
\end{tabular}

Overall, the first problem stated that how many homestay employees understood the job desk as well as functional competency standard by the respondents as employee or host said that they were very capable and can do those kinds of job desk. The average values of being a capable receptionist is up to 4,28 , the average value of being a telephone operator is up to 4,36, and the average value of being capable is up to 4,64 . Those average values have a high-grade explanation that can handle guests' skill in Front Office Division. The skills and qualifications of front desk employees are very important, as these employees play a significant role in building and maintaining the lodge industry image and reputation.

The second problem statement, even most employees know very well about their job desk, unfortunately, they have not certified. It will be the next programmed from the local government to hold the certification for them.

Furthermore, the third problem statement advances homestay front office human resources by developing their knowledge, skill, and attitude. The employee average value up to 4,38 explained that they know their responsibility and roles besides do their functional competency standard. Besides, the employee must be certified to be competent in the workplace. To make sure that they are competent as well as their job desks, they must be certified and legal. Human resources management is an organization consists of people with formally assigned roles who work together to achieve the organization's goals [20]. Moreover, employees and organizations focus on the portfolio of skills that suit individuals for specific roles within an organization, and less on the "job" as traditionally defined. Competency requires the ability to apply relevant skills, knowledge, and attitudes consistently over time in the required workplace situations and environments. When the employee practices their competency in the workplace, service quality will develop during the services of the guest.

\section{Conclusions}

This research is concerning in homestay employee practices their workplace competency standard to increase service quality. Homestay concepts are community-based tourism, where the host as well as an employee do their job as a receptionist, telephone operator, and bell boy. In the case of Front Office Division, it could be handled by them, recognition of the job desk and must be certified. This descriptive research explained homestay as accommodation is a term associated with a private house, a particular culture, and interaction with a host or a family in every space becomes a public area [28]. Apart from the authentic experience and architectural of the host culture, homestay can offer cultural adventure [4]. Living in a homestay, tourists have the opportunity to experience firsthand the life of local 
families, with the comfort and simplicity of local characteristics. The success of the homestay business depends on the owner's capability as host and operator, which are characteristics of small and medium businesses [5]. During conducted the research, employee and host as respondents very helpful and give suggest related to the research.

The findings explained three problem statements. The first problem stated that how many homestay employees understood the job desk as well as functional competency standards by the respondents as employee or host. The respondents were very capable and can do those kinds of job desk. Those average values have a high-grade explain that they can handling guests and have skill in Front Office Division. The skills and qualifications of front desk employees are very important, as these employees play a significant role in building and maintaining the lodge industry image and reputation.

The second problem statement, even most employees know very well about their job desk, unfortunately, they are not certified yet. It will be the next program from the local government to hold the certification for them. To make sure that they are competent as well as their job desks, they must be certified and legal.

The third problem statement advances homestay front office human resources by developing their knowledge, skill, and attitude. Overall, the employee knew their responsibility and roles besides does their functional competency standard. In addition, the employee must be certified to be competent in the workplace. Competency requires the ability to apply relevant skills, knowledge, and attitudes consistently over time, and in the required workplace situations and environments. When the employment practices and advance their competency in the workplace, service quality will develop by them during services the guest. Hopefully, they will be the competent human resources in the hospitality industry as well as their job desk.

For further research, there is two suggestion for the industry and local government in Kupang City. The first, make training related to Hospitality and Hotel skill. The training for the employee will specify their job desk as a receptionist to handling guest services, with hospitality standards and list competency standards in the workplace. The second, training of homestay management based on ASEAN Homestay Standard. The objective of this standard is to develop a comprehensive homestay standard that can be adapted by the ASEAN Member States as recommended in the ASEAN Tourism Strategic Plan (ATSP) in 2011 - 2015 to create quality visitor experience by showcasing their rural resources in a presentable, safe, and attractive manner.

The homestay program is a form of alternative tourism in which tourists allowed to experience the way of life in a typical village with the local community. The experiential nature of this form of tourism is becoming increasingly popular with foreign tourists. In contrast to mass tourism, the homestay programmed should preferably be low scale, low density, flexible and spontaneous. Importantly, it should be owned and operated by the local communities so that the economic benefits go directly to them [29].

\section{References}

[1] The Central Bureau of Statistics of East Nusa Tenggara Province, Indonesia (2018)

[2] Pujaastawa, I.B.G.dkk.: Pariwisata Terpadu Alternatif Model Pengembangan Pariwisata Bali Tengah. Universitas Unidaya, Denpasar (2005).

[3] Arefin, A.T. et, al: The Empowerment Model of Coastal Homestay Business Owners in Five Strategic Area of National Tourism. International Journal of Administrative 
Science \& Organization, Bisnis \& Birokrasi, Jurnal Ilmu Administrasi dan Organisasi, Vol. 21 (Januari 2014).

[4] Cole, S.: Beyond Authenticity and Co modification. Annals of Tourism Research, 349(4), 943-960 (2007).

[5] Carter, W.K.: Akuntansi Biaya "Cost Accounting". Salemba Empat, Jakarta (2009).

[6] Vajirakachom, T.: Determinant of Success for Community Based Tourism: The Case of Floating Markets in Thailand, Thailand (2011).

[7] Kayat, K. (2002). Exploring factors influencing individual participation in community based tourism: The case of Kampung relau homestay program, Malaysia. Asia Pacific Journal of Tourism Research, (March 2015). http://doi.org/10.1080/10941660208722116

[8] Kelvin, Y.: A Conceptual Framework of Community Participation and Enterpreunerial Success Towards the Homestay Business in Sabah, Malaysia. Academy of Enterpreneuship Journal Vol.25, University Malaysia Sabah, Sabah (2019.

[9] Hussin, R., \& Fernando, J.M.: Ecotourism and Community Participation in the Homestay Programme of Sukau Village: Long-Term or Limited Benefits, University Malaya (2008)

[10] Yoeti, Oka.: Dasar-Dasar Pengertian Hospitality Pariwisata. PT. Alumni, Bandung (2010).).

[11] Gunawan, M.P: Pariwisata Membangun Bangsa dalam Pariwisata Indonesia. Vol.4, Pusat Perencanaan dan Pembangunan Kepariwisataan ITB, Bandung (2005).

[12] Ardika, Dyana.: Pariwisata Budaya Berkelanjutan, Refleksi dan Harapan di Tengah Perkembangan Global. Program Pasca Sarjana, Universitas Udayana, Denpasar (2004).

[13] Natori, Nasahiko.: A Guide Book for Tourism Based Community Development. Publiser APTEC, Osaka Japan (2001).

[14] Lynch, P.A.: Networking in the Homestay Sector. The Service Industries Journal ABI/INFORM Global. 20(3):95-100 (2000)).

[15] Sundaram, D. S., and Cynthia W. The role of nonverbal communication in service encounters. Journal of Services Marketing 14.5: 378-391 (2000).

[16] Agusnawar.: Pengantar Operasional Kantor Depan Hotel. PT. Perca Jakarta, Jakarta (2001).

[17] Seijts, G. Copying with Complexity. Western University: Ivey Business Journal (2010).

[18] Pfeffer, J.: Competative Advantage Through People: Unleashing the Power of Work Force. Boston: Harvard Business School Press (1994).

[19] Warhurst \& Nickson.: Employe experience of aesthetic labour in retail and hospitality. Work, Employment and Society, 21(1), pp. 103-120 (2007).

[20] Dessler, Gary.: Manajemen Sumber Daya Manusia. Penerbit Indeks, Jakarta (2011).

[21] Carter, W.K.: Akuntansi Biaya "Cost Accounting". Salemba Empat, Jakarta (2009).

[22] Internasional Labour Organization.: Human Resources Development Recommendation. No. 195 (2004).

[23] National Occupational Certification Schemes Referencing to ACCSTP And CATC on Tourism Professional in the area of Front Office, Ministry of Tourism of Indonesia, Jakarta (2015).

[24] Kotler, Philip, and Amstrong,G.: Marketing An Introduction. Fourth Edition, Prentince Hall International, New Jersey (1997).

[25] Tjiptono, Fandy.: Strategi Pemasaran. Edisi 3, Andy, Yogyakarta (2008). 
[26] Sharon \& Nor.: Local Perceptions Towards Tourism Impacts Related to Homestay Programme. Journal of Management Research. ISSN 1941-899X 2015 Vol 7, Macrothink Institute (2015).

[27] Data Results using SPSS 23

[28] Lynch, P.A.: Networking in the Homestay Sector. The Service Industries Journal ABI/INFORM Global. 20(3):95-100 (2000).

[29] ASEAN Homestay Standard (2016) 